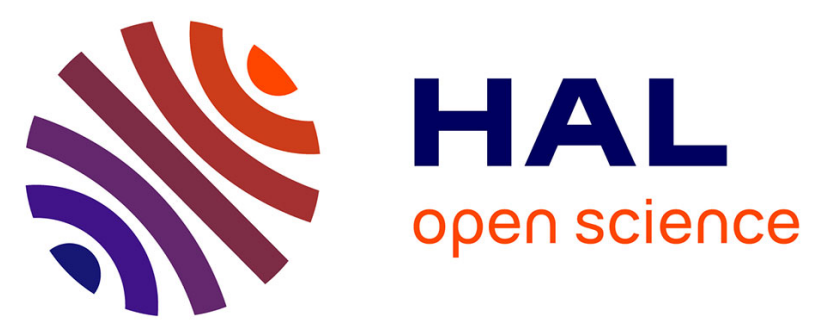

\title{
Pre-treatment of a sugarcane bagasse-based substrate prior to saccharification: effect of coffee pulp and urea on laccase and cellulase activities of Pycnoporus sanguineus
}

Enrique González Bautista, Enrique Gutierrez, Nathalie Dupuy, Isabelle Gaime-Perraud, Fabio Ziarelli, Anne Marie Farnet da Silva

\section{To cite this version:}

Enrique González Bautista, Enrique Gutierrez, Nathalie Dupuy, Isabelle Gaime-Perraud, Fabio Ziarelli, et al.. Pre-treatment of a sugarcane bagasse-based substrate prior to saccharification: effect of coffee pulp and urea on laccase and cellulase activities of Pycnoporus sanguineus. Journal of Environmental Management, 2019, 239, pp.178-186. 10.1016/j.jenvman.2019.03.033 . hal-02073560

\author{
HAL Id: hal-02073560 \\ https://hal.science/hal-02073560
}

Submitted on 20 Mar 2019

HAL is a multi-disciplinary open access archive for the deposit and dissemination of scientific research documents, whether they are published or not. The documents may come from teaching and research institutions in France or abroad, or from public or private research centers.
L'archive ouverte pluridisciplinaire HAL, est destinée au dépôt et à la diffusion de documents scientifiques de niveau recherche, publiés ou non, émanant des établissements d'enseignement et de recherche français ou étrangers, des laboratoires publics ou privés. 
Research article

\title{
Pre-treatment of a sugarcane bagasse-based substrate prior to saccharification: Effect of coffee pulp and urea on laccase and cellulase activities of Pycnoporus sanguineus
}

\author{
Enrique González Bautista ${ }^{\mathrm{a}, \mathrm{b}}$, Enrique Gutierrez ${ }^{\mathrm{b}}$, Nathalie Dupuy ${ }^{\mathrm{a}}$, Isabelle Gaime-Perraud ${ }^{\mathrm{a}}$, \\ Fabio Ziarelli ${ }^{\mathrm{c}}$, Anne-Marie Farnet da Silva, ${ }^{\mathrm{a}, *}$ \\ ${ }^{a}$ Aix Marseille Université, Avignon Université, CNRS, IRD, IMBE, Marseille, France \\ ${ }^{\mathrm{b}}$ Instituto de Biotecnología y Ecología Aplicada (INBIOTECA), Universidad Veracruzana, Campus para la Cultura, las Artes y el Deporte, Av. de las Culturas Veracruzanas \\ No. 101Col. Emiliano Zapata, C.P. 91090, Xalapa, Veracruz, Mexico \\ ${ }^{\mathrm{c}}$ Aix Marseille Université, CNRS, Spectropole Campus St Jérôme, Fédération des Sciences Chimiques de Marseille, FR 1739, 13397, Marseille, France
}

\begin{abstract}
A B S T R A C T
Production of second-generation bioethanol uses lignocellulose from agricultural by-products such as sugarcane bagasse (SCB). A lignocellulose pre-treatment is required to degrade lignin, ensuring further efficient saccharification. Two experimental designs were set up to define culture conditions of Pycnoporus sanguineus in mesocosms to increase laccase activities and thus delignification. The first experimental design tested the effect of phenolic complementation (via coffee pulp) and the use of urea as a simple nitrogen source and the second defined more precisely the percentages of coffee pulp and urea to enhance delignification. The responses measured were: lignocellulolytic activities, laccase isoform profiles by sodium dodecyl sulfate-polyacrylamide gel electrophoresis (SDS-PAGE) and the chemical transformation of the substrate using solid-state NMR of 13C. Adding $10 \%$ of coffee pulp increased laccase activities and fungal biomass (32.5\% and $16 \%$ respectively), enhanced two constitutive isoforms $\left(\mathrm{R}_{\mathrm{f}} 0.23\right.$ and 0.27$)$, induced a new isoform $\left(\mathrm{R}_{\mathrm{f}} 0.19\right)$ and led to a decrease in total aromatics. However, higher concentrations of coffee pulp (25\%) decreased laccase and cellulase activities but no decrease in aromaticity was observed, potentially due to the toxic effect of phenols from coffee pulp. Moreover, laccase production was still inhibited even for lower concentrations of urea (0-5\%). Our findings revealed that an agricultural by-product like coffee pulp can enhance laccase activity -though to a threshold- and that urea limited this process, indicating that other $\mathrm{N}$-sources should be tested for the biological delignification of SCB.
\end{abstract}

\section{Introduction}

Because of the increment of global population, the demand for energy has increased about 13-fold during the 20th century (Gupta and Verma, 2015). The use of fossil-fuel-based energy has provoked climate change and concerns about energy supply, which strengthened the interest in alternative renewable sources of energy like biofuels (Koppram et al., 2014). The current industrial production of bioethanol (first generation) mainly relies on starch-containing crops (i.e. sweet-corn, sugarcane and sweet-sorghum). On the other hand, ethanol produced from lignocellulose (second generation) does not compete for arable lands and uses lignocellulosic biomass from wastes (i.e. SCB, wheat straw, corn cobs, etc.) (Koppram et al., 2014). This type of biomass is one of the most abundant on earth, storing about $14 \%$ of the total global energy (Gupta and Verma, 2015).

The process to obtain second-generation ethanol requires a pretreatment i.e. delignification of the substrate, then hydrolysis of cellulose and hemicellulose (saccharification), sugar fermentation and purification of ethanol to reach fuel specifications (Mosier et al., 2005). However, one of the most challenging steps prior saccharification, is to increase the availability of polysaccharides for enzymes by delignification of plant fibres. Many types of physicochemical, chemical and biological pre-treatments have been developed to achieve this goal (Alvira et al., 2010). Off all these strategies, biological pre-treatments using white-rot fungi involve no chemical hazard unlike other methods but they have never been used for second-generation bioethanol production. White-rot fungi are known to produce phenoloxidases (Baldrian, 2006; Sinsabaugh, 2010): lignin peroxidases (LiP) (Hammel

\footnotetext{
* Corresponding author.

E-mail address: anne-marie.farnet@imbe.fr (A.-M. Farnet da Silva).
} 
et al., 1986), manganese peroxidases (MnP) (Sack et al., 1997) and laccases (Collins et al., 1996). These enzymes can enhance dephenolisation of lignocellulose and thus make polysaccharides more available for subsequent enzymatic hydrolysis during saccharification (Singh et al., 2008; Mood et al., 2013). Laccases (benzenediol/oxygen oxidoreductase, EC 1.10.3.2) are non-specific blue multicopper oxidases, which catalyse one-electron oxidation of various phenolic compounds and use molecular oxygen as the final electron acceptor (D'Agostini et al., 2015). Due to that potential, laccase can be used in biological pretreatment for delignification (thermostability, low substrate specificity), and promotion of its production has attracted much attention.

Production of laccases is influenced by nutrient levels (Dekker et al., 2007), fermentation parameter conditions such as culture time, shaking, temperature (Vasconcelos et al., 2000), and fungal growth stage (Chen et al., 2003) as well as the addition of a wide range of inducers to culture media (Minussi et al., 2007). Laccase gene transcription is regulated by various aromatic compounds related to lignin or lignin derivatives (Mansur et al., 1998; Janusz et al., 2006; Periasamy and Palvannan, 2010). Laccase production is also regulated by the type and concentration of nitrogen source in the medium (Kachlishvili et al., 2006; D'Agostini et al., 2015; Hernández et al., 2015). Organic nitrogen sources like urea or yeast extract usually lead to high laccase yields and good fungal growth (Arora and Rampal, 2002). However, there is no clear consensus concerning laccase production and nitrogen complementation: various tendencies were observed depending on the white-rot fungi and the type of nitrogen source (Piscitelli et al., 2011). Urea has been used as a nitrogen source for laccase production from $P$. sanguineus in solid-state fermentation (SSF) (Vikineswary et al., 2006). Reddy et al. (2003) reported that urea at $40-50 \%$ of total nitrogen in the substrate stimulated fungal growth. This is thus of huge importance to determine the amount of nitrogen added in cultures in order to enhance laccase activity and lignin degradation without reaching inhibition concentrations.

Sugarcane is one of the most produced crops in the world: 42.8 million tons of bagasse were produced from juice extraction of milled sugarcane all around the world in 2010, and this agricultural waste can thus be used for second-generation ethanol production (Gupta and Verma, 2015). Similarly, coffee pulp is a primary by-product obtained during coffee processing (234000 tons were produced in Mexico in 2016) and is an environmental concern because of the toxicity of caffeine and tannins (Pandey et al., 2000). This by-product has been used to enhance the production of laccase enzymes in white-rot fungi (Bhat, 2000; Niladevi and Prema, 2008). Thus, both by-products can complement each other to produce a suitable substrate which can be used in a process integrating a biological pre-treatment based on white-rot fungus potential of delignification. This study aimed at defining the amounts of coffee pulp and urea added to SCB to enhance and/or induce laccase activities of $P$. sanguineus and therefore degradation of lignin. To our knowledge this is the first report about the use i) of a white-rot fungus in the delignification pre-treatment of lignocellulose for second-generation ethanol production and ii) of coffee pulp as an inducer of laccase activities in such context.

A response surface experimental design was performed to test the influence of two factors (coffee pulp and urea) on the delignification of SCB. As responses, laccase and cellulase activities were measured and transformation of lignocellulose was evaluated by measuring the amount of total phenolics, cellulose, and the degree of cellulose crystallinity by solid-state ${ }^{13} \mathrm{C} \mathrm{CP} / \mathrm{MAS}$ NMR. The potential induction of laccase isoforms by the addition of coffee pulp was followed by sodium dodecyl sulfate-polyacrylamide gel electrophoresis (SDS-PAGE).

\section{Materials and methods}

\subsection{Fungal strain and preparation of the inoculum}

The strain of $P$. sanguineus used was isolated from a wild mushroom found in the sugarcane fields of Jalcomulco, Veracruz, Mexico $\left(19^{\circ} 20^{\prime} 00^{\prime \prime} \mathrm{N}, 96^{\circ} 46^{\prime} 00^{\prime \prime} \mathrm{W}\right)$ and preserved in a potato-dextrose-agar medium (PDA) at $4^{\circ} \mathrm{C}$. The collected fungus was identified by RamírezGuillén F., a classical taxonomy expert, and deposited at XAL Herbarium (INECOL A.C., Xalapa, Mexico) as F. Ramírez-Guillén 932. The fungal strain was also identified by sequencing ITS 1 and ITS 4 regions, compared with sequences in GenBank and the DNA sequence obtained was deposited in GenBank under the accession number KR013138 (Hernández et al., 2016).

The fungal strain was reactivated in plates of malt extract agar $1.5 \%$ at $30{ }^{\circ} \mathrm{C}$ for seven days. Five round agar pieces of $1 \mathrm{~cm}$, after seven days of growth, were used as inoculum to propagate the strain in sorghum grain plates, they were incubated for 10 day at $30^{\circ} \mathrm{C}$ and sorghum grains were pre-rinsed two times and kept in water overnight. $150 \mathrm{~mL}$ of water and $0.5 \mathrm{~g}$ of gypsum were added for every $100 \mathrm{~g}$ of sorghum used, then sterilised by autoclaving. The inoculum for the SSF was $5 \%$ of the total substrate mass (Hernández et al., 2017).

\subsection{Experimental design}

To evaluate delignification of the SCB by $P$. sanguineus two factorial designs were used (Tables 1 and 2), where the independent variables were: the amount of exogenous source of phenolic compounds (coffee pulp) and the amount of nitrogen source (urea). The first experimental design helped to understand how the factors tested (urea and coffee pulp) influenced lignocellulolytic activities of the fungus and thus SCB dephenolisation. For each factor, three concentrations ranging from 0 to $10 \%$ were tested. Then, a more specific experimental design was performed, using 5 concentrations for each factor: the amount of urea was lowered from 0 to $5 \%$ to avoid catabolic repression without limiting nitrogen (Piscitelli et al., 2011) and coffee pulp concentrations were higher (from 10 to 25\%) to test to which extent coffee pulp addition can enhance laccase activities and thus dephenolisation of the substrate. The dependent variables measured were: laccase and cellulase activities, and the chemical characterization of the substrate using solid-state ${ }^{13} \mathrm{C}$ CP/MAS NMR. A $\{p, n\}$ simplex-lattice design for $p$ components consists of points defined by the following coordinate settings: the proportions assumed by each component take the $n+1$ equally spaced values from 0 to 1 ,

$x_{i}=0,1 / n, 2 / n, \ldots, 1$ for $i=1,2, \ldots, p$

All possible combinations (mixtures) of the proportions from this equation were used (Tables 1 and 2). Considering a three-component mixture for which the numbers of spaced levels for each component are three and five (first and second experimental design). The centre point was triplicate to obtain a repeatability idea of the data. The following polynomial equation of function $\mathrm{Xi}$ was fitted for each factor assessed at each experimental point. The polynomial model Eq. (1) was used:

$Y=b 1 \times 1+b 2 \times 2+b 3 \times 3+b 12 \times 1 \times 2+b 13 \times 1 \times 3+b 23 \times 2 \times 3)$

\section{Table 1}

Factors and levels evaluated in the first experimental design (coffee pulp ranging from 0 to $10 \%$ and urea from 0 to $10 \%$ ).

\begin{tabular}{llll}
\hline No. & Coffee Pulp (\%) & Urea (\%) & Bagasse (\%) \\
\hline 1 & 0 & 0 & 100 \\
2 & 10 & 10 & 80 \\
3 & 5 & 10 & 85 \\
4 & 10 & 5 & 85 \\
5 & 10 & 0 & 90 \\
6 & 0 & 10 & 90 \\
7 & 5 & 0 & 95 \\
8 & 0 & 5 & 95 \\
9 & 5 & 5 & 90 \\
\hline
\end{tabular}


Table 2

Factors and levels evaluated in the second design of experiments (coffee pulp ranging from 0 to $25 \%$ and urea from 0 to $5 \%$ ).

\begin{tabular}{llll}
\hline No. & Coffee Pulp (\%) & Urea (\%) & Bagasse (\%) \\
\hline 1 & 13,1 & 1,3 & 85,6 \\
2 & 17,5 & 0,0 & 82,5 \\
3 & 10,0 & 5,0 & 85,0 \\
4 & 10,0 & 2,5 & 87,5 \\
5 & 25,0 & 0,0 & 75,0 \\
6 & 16,3 & 2,5 & 81,3 \\
7 & 13,1 & 3,8 & 83,1 \\
8 & 20,0 & 5,0 & 75,0 \\
9 & 22,5 & 2,5 & 75,0 \\
10 & 10,0 & 0,0 & 90,0 \\
11 & 20,6 & 1,3 & 78,1 \\
12 & 15,0 & 5,0 & 80,0 \\
\hline
\end{tabular}

Where $\mathrm{Y}$ is the estimated response; $\mathrm{b}_{1}, \mathrm{~b}_{2}, \mathrm{~b}_{3}, \mathrm{~b}_{12}, \mathrm{~b}_{13}$, and $\mathrm{b}_{23}$ are constant coefficients for each linear and interaction term produced for the prediction models of processing components. The significance level was considered at $\alpha=0.05$ in all calculations. The correlations between the parameters were determined using UNSCRAMBLER X 10.4 (CAMO). To find out whether the independent variables have significant effects on each response, a two-way ANOVA was carried out. Homoscedasticity and normality were analysed previously. The combined effect of urea and coffee pulp concentrations in the medium was analysed by response surface methodology (Box and Wilson, 1992).

\subsection{Mesocosm preparation}

The SCB and coffee pulp were previously milled and sterilised by autoclave, the SCB was sterilised using plastic bags at $30 \%$ of humidity, the coffee pulp was sterilised by autoclaving using flasks of $125 \mathrm{~mL}$ and the humidity was adjusted at the end to $80 \%$. The mesocosms were placed in $2.6 \mathrm{~L}$ glass jars $\left(21 * 16 * 6 \mathrm{~cm}^{3}\right)$ containing $70 \mathrm{~g}$ of the substrate (dry weight, DW) per mesocosm, covered with pierced lids for oxygen diffusion. For each experiment (Tables 1 and 2), mesocosms were realised in three replicates $(n=3)$, thus, a total of 28 or 36 mesocosms (for the first and second experimental design) were prepared and incubated at $30{ }^{\circ} \mathrm{C}$ at $80 \%$ of the WHC in the dark for 1 month. Humidity was maintained constant over incubation at $80 \%$ of the WHC by adding sterilised water.

\subsection{Enzymatic activities}

Laccases and cellulases were quantified after a 1-month incubation. The reaction mixtures for all the enzyme activities performed with the enzyme extract consisted of $3 \mathrm{~g}$ of the substrate with $8 \mathrm{~mL}$ of the corresponding buffer $30^{\circ} \mathrm{C}$ for laccases and $50^{\circ} \mathrm{C}$ for cellulases. Laccase activity was measured by monitoring the oxidation of syringaldazine to its quinone $\left(\varepsilon^{\mathrm{M}}=65000 \mathrm{M}^{-1} \mathrm{~cm}^{-1}\right)$ at $525 \mathrm{~nm}$ in acetate buffer (100 mM, pH 4.5) (Farnet et al., 2004). CM-cellulase (EC 3.2.1.4) activity was assayed using Carboxy Methyl Cellulose (CMC) at $0.1 \%(\mathrm{w} / \mathrm{v})$ as substrate with sodium acetate buffer $(50 \mathrm{mM}, \mathrm{pH} 5)$. After a $3 \mathrm{~h}$ incubation, glucose was quantified according to the Somogyi-Nelson method and absorption was read at $870 \mathrm{~nm}$ (Farnet et al., 2010). All analytical experiments were performed in triplicate for each mesocosm. One unit (U) of enzyme activity is defined as one $\mu$ mole of the reaction product formed per $\mathrm{h}$ and per $\mathrm{g}$ of dry weight $(\mathrm{dw})$.

\subsection{Solid-state ${ }^{13} \mathrm{C} C P / M A S$ NMR}

Each mesocosm at t0 and after incubation was chemically characterised by solid-state ${ }^{13} \mathrm{C} \mathrm{CP} / \mathrm{MAS}$ NMR on a spectrophotometer Bruker DSX $400 \mathrm{MHz}$ operating at $100.7 \mathrm{MHz}$. Samples (400 mg) were spun at $10 \mathrm{kHz}$ at the magic angle. Contact times of $2 \mathrm{~ms}$ were applied with a pulse width of $2.8 \mu$ s and a recycle delay of $3 \mathrm{~s}$. Chemical shift values were referenced to tetra-methyl-silane and calibrated to glycine carbonyl signal set at $176.03 \mathrm{ppm}$. The relative $\mathrm{C}$ distribution in ${ }^{13} \mathrm{C}$ NMR spectra was determined by integrating the signal intensity in different chemical shift regions (Massiot et al., 2002), with an integration routine supplied with Dmfit 2003 software. Seven common chemical shift regions were defined according to Mathers and $\mathrm{Xu}$ (2003): Alkyl-C (0-45 ppm), methoxyl-C (46-60 ppm), O-Alkyl-C (61-91 ppm), di-O-Alkyl-C (92-112 ppm), aromatic-C (112-142 ppm), phenolic-C (142-160 ppm) and carboxyl-C (160-185 ppm. Two decomposition indexes have been calculated according to Baldock et al. (1997): (Alkyl-C/O-Alkyl-C) as the humification ratio and an aromaticity ratio by dividing the sum of aromatic-C and phenolic- $\mathrm{C}$ to the sum of all regions except methoxyl-C; the crystallinity of cellulose of the substrate after the experiment was also measured using crystalline cellulose $(90 \mathrm{ppm}) /$ amorphous plus crystalline cellulose (83 and 90 ppm) (Park et al., 2010).

\subsection{Characterization of laccase isoform patterns}

SDS-PAGE under semi-denaturalizing conditions were carried out according to Farnet et al. (2004) using 4\% stacking gel and $15 \%$ separating gel at $220 \mathrm{~V}$ with the Mini-Protean II electrophoresis cell (BioRad). Laccase isoforms were revealed using laccase activity staining: gels were immersed for $30 \mathrm{~min}$ in acetate buffer, $0.1 \mathrm{M}$, pH 4.5, with $p$ phenylenediamine $0.1 \%$ as laccase substrate and the $R_{f}$ was calculated for each isoform.

\section{Results}

3.1. The effect of coffee pulp and urea addition on lignocellulolytic activities and chemical properties of the substrate

Ideally, the addition of urea and coffee pulp has to lead to enhanced laccase activities, while avoiding degradation of polysaccharides within the SCB. For laccase activities, ANOVA results showed a significant effect ( $\mathrm{p}<0.001$ ) of urea in interaction with either SCB or coffee pulp (Table 3). According to the surface plots obtained, the interactions between urea and coffee pulp (Fig. 1a) or urea and SCB (Fig. 1b), showed a negative effect of urea on laccase activities ( $p<0.001$ ). On the other hand, coffee pulp had a strong significant effect alone ( $p<0.001)$ on laccase activities that were enhanced $(32.5 \%$ more than control when using $10 \%$ of coffee pulp) by the addition of these agricultural residues rich in phenols. SDS-PAGE revealed that coffee pulp at $10 \%$ enhanced the production of the two constitutive laccase isoforms with $\mathrm{R}_{\mathrm{f}}=0.23$ and 0.27 and of an induced another isoform with $R_{\mathrm{f}}=0.19$.

ANOVA results showed significant effects $(p<0.001)$ of coffee pulp in interaction with SCB on cellulase activities (Table 3). Analysing the interaction surface plots between coffee pulp and bagasse (data not

Table 3

Three-way ANOVA testing the effect of coffee pulp (CP, 0-10\%) and urea (U $0-10 \%$ ) in SCB (B) on lignocellulolytic activities and chemical properties of the substrate after a one-month incubation.

\begin{tabular}{lllllll}
\hline \multirow{2}{*}{ Response } & $\begin{array}{l}\text { Coffee } \\
\text { Pulp (CP) }\end{array}$ & Urea (U) & Bagasse (B) & CP*U & CP*B & U*B \\
\hline Laccase activity & +++ & +++ & +++ & +++ & $\mathrm{NS}$ & +++ \\
Cellulase activity & $\mathrm{NS}$ & $\mathrm{NS}$ & $\mathrm{NS}$ & $\mathrm{NS}$ & +++ & $\mathrm{NS}$ \\
Aromatics & $\mathrm{NS}$ & + & +++ & +++ & $\mathrm{NS}$ & + \\
O-Alkyl & $\mathrm{NS}$ & + & +++ & +++ & + & +++ \\
Methoxyl-C & $\mathrm{NS}$ & $\mathrm{NS}$ & $\mathrm{NS}$ & $\mathrm{NS}$ & $\mathrm{NS}$ & $\mathrm{NS}$ \\
Aromaticity ratio & $\mathrm{NS}$ & + & +++ & +++ & $\mathrm{NS}$ & + \\
Crystallinity & $\mathrm{NS}$ & $\mathrm{NS}$ & $\mathrm{NS}$ & $\mathrm{NS}$ & $\mathrm{NS}$ & $\mathrm{NS}$ \\
Alkyl-C/COOH & + & $\mathrm{NS}$ & $\mathrm{NS}$ & $\mathrm{NS}$ & + & $\mathrm{NS}$ \\
\hline
\end{tabular}

(NS $=$ Non significant, $+\mathrm{p}<0.05,++\mathrm{p}<0.01,+++\mathrm{p}<0.001$ ). 

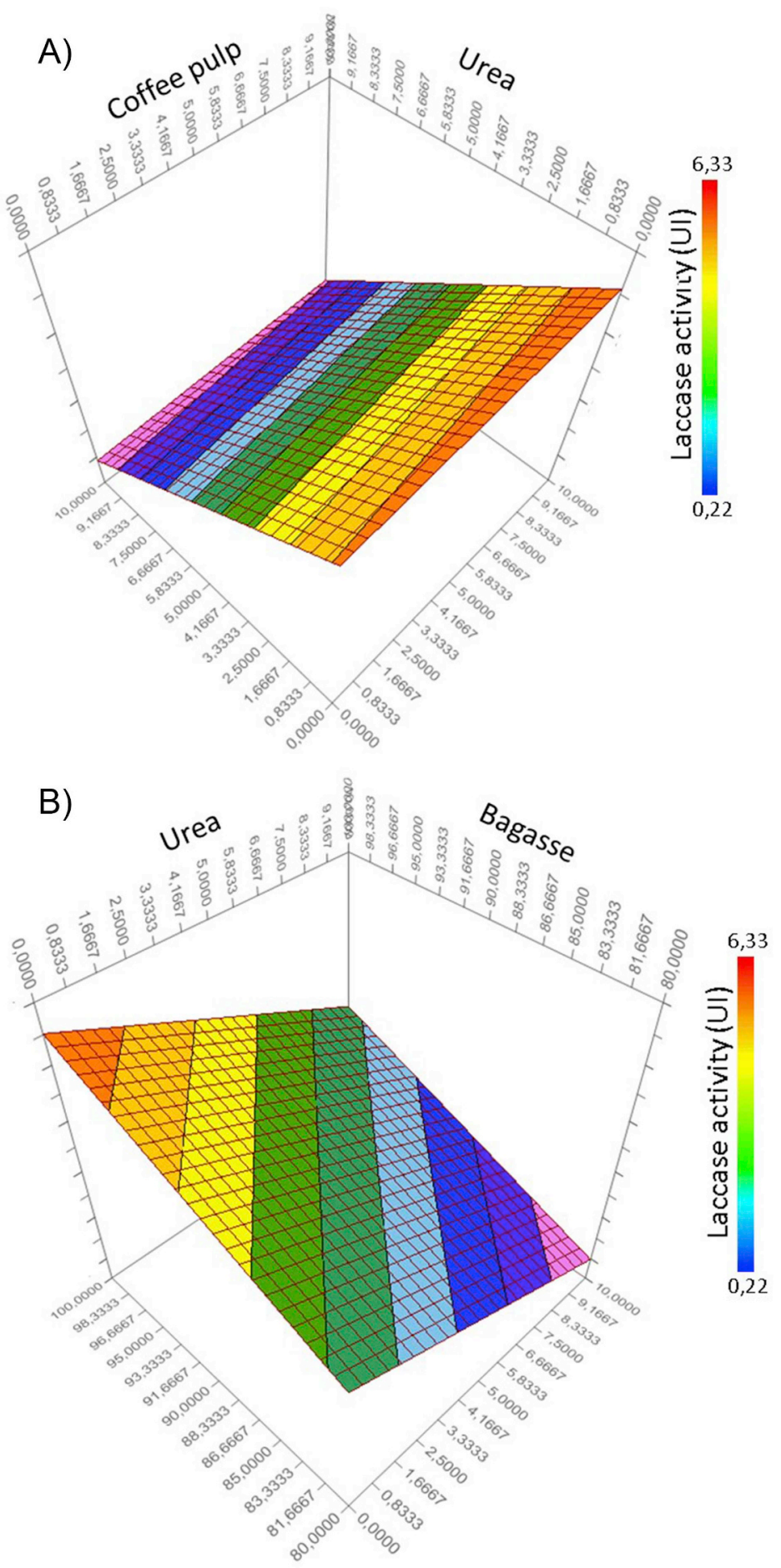

Fig. 1. Laccase activity surface plots showing interactions between Urea and coffee pulp (A) and Bagasse and urea (B) during the first experimental design (Coffee pulp $0-10 \%$, Urea $0-10 \%)$.

shown), we observed that these activities increased when both factors were at the maximum level i.e. $10 \%$ and $100 \%$ respectively, proving that mixing coffee pulp and bagasse can enhance such activities.

At t0, no differences in aromaticity ratio or methoxyl-C signals (linked to lignin) were found between all the substrates (data not shown). In order to determine the degree of substrate delignification, the aromaticity ratio was calculated at the end of incubation and ANOVA showed a significant effect of interactions between urea and coffee pulp ( $p<0.01$ ) on aromaticity ratio: it increased with urea, while it decreased with coffee pulp (Fig. 2a). Interestingly, the crystallinity of cellulose (crystalline cellulose/amorphous cellulose) was never significantly affected no matter the factor considered (Table 3). This result indicates that crystalline cellulose was barely hydrolysed during a one-month incubation.

For AlkylC/COOH ratio, ANOVA (Table 3) showed the effect of the interaction between coffee pulp and SCB on this ratio: Alkyl-C/COOH ratio increased with coffee pulp (Fig. 2b). When analysing the coffee pulp effect alone, we observed an increase in $16 \%$ of Alkyl-C/COOH using the highest concentration of coffee pulp without urea $(\mathrm{p}<0.05)$ compared to control. 

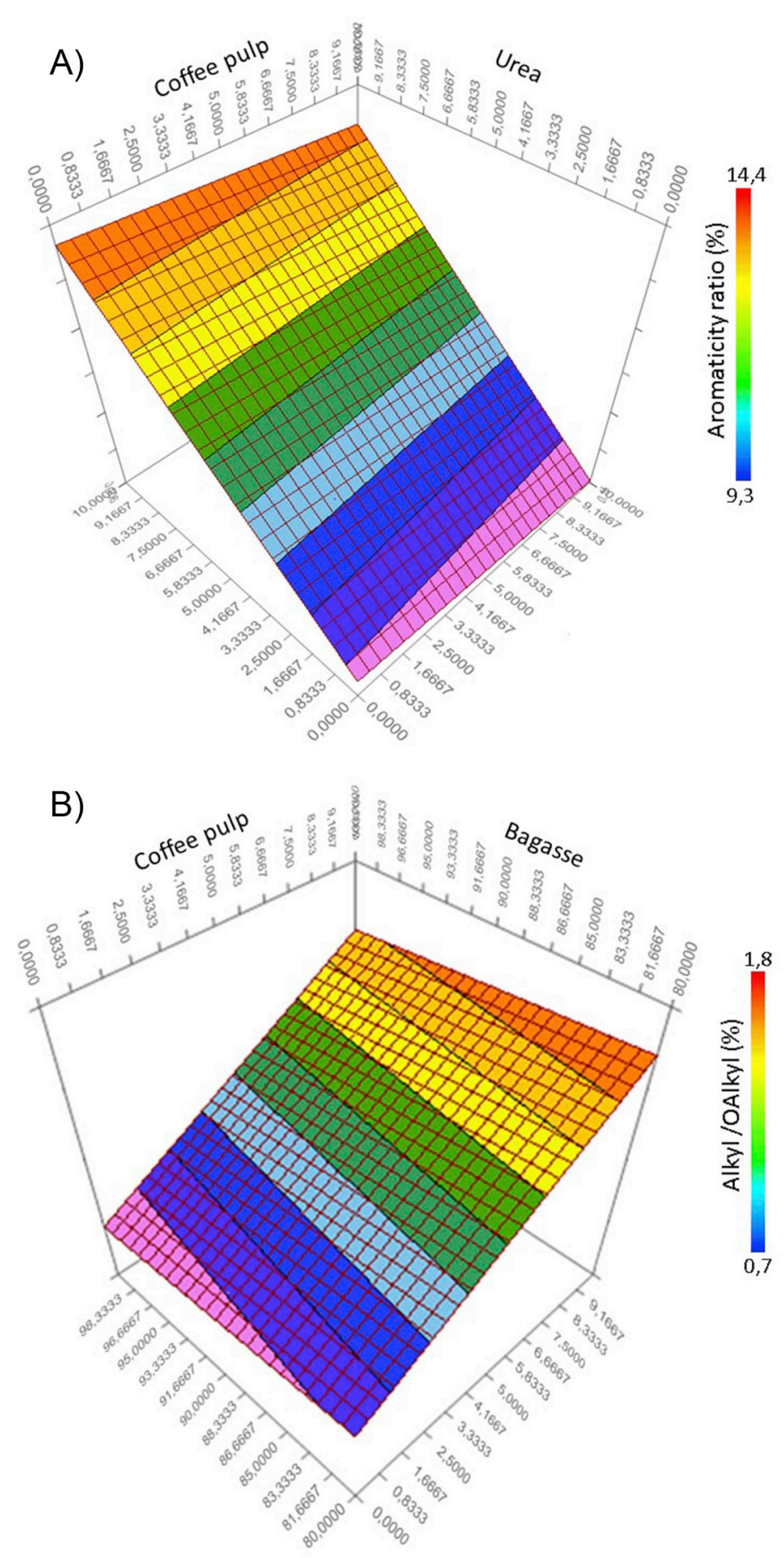

Fig. 2. Aromaticity ratio showing surface plots interactions between coffee pulp and urea (A) and Alkyl-C/O-Alkyl-C ratio surface plots showing interactions between coffee pulp and bagasse (B) during the first experimental design (Coffee pulp 0-10\%, Urea 0-10\%).

\subsection{Defining to what extent coffee pulp and urea can modify laccase activities}

For the second experimental design (Table 2), lower concentrations of urea were assayed to determine to what extent urea can affect laccase activities. ANOVA revealed a significant effect $(\mathrm{p}<0.05)$ of urea addition on laccase activities (Table 4). Analysing the surface plot interaction between urea and SCB, we observed an inhibitory effect on laccase activities with the addition of urea but to a lesser extent compared to that found in the first experimental design (data not shown). ANOVA also showed the effect of higher amounts of coffee pulp on laccase activities, which differed from the results of the first experimental design. The addition of a higher quantity of coffee pulp indeed led to a decrease in laccase activities (Fig. 3) and this suggests that coffee pulp can enhance laccase activities of $P$. sanguineus up to a threshold. SDS-PAGE revealed the same results as those obtained when adding $10 \%$ of coffee pulp i.e. an enhanced production of the two constitutive laccase isoforms and another induced isoform produced.

Interestingly, for cellulases, we found a significant effect of interaction between urea and coffee pulp $(p<0.001)$. An increase in urea (even for lower concentrations i.e. 0-5\%) together with a decrease in coffee pulp concentrations enhanced cellulase activities (Fig. 4). An 
Table 4

Three-way ANOVA testing the effect of coffee pulp (CP, 0-25\%) and urea (U, $0-5 \%$ ) in SCB (B) on lignocellulolytic activities and chemical properties of the substrate after a one-month incubation.

\begin{tabular}{lllllll}
\hline \multirow{2}{*}{ Response } & $\begin{array}{l}\text { Coffee } \\
\text { Pulp (CP) }\end{array}$ & Urea (U) & Bagasse (B) & CP*U & CP*B & U*B \\
\hline Laccase activity & ++ & $\mathrm{NS}$ & +++ & $\mathrm{NS}$ & +++ & $\mathrm{NS}$ \\
Cellulase activity & $\mathrm{NS}$ & + & +++ & +++ & + & + \\
Aromatics & $\mathrm{NS}$ & ++ & $\mathrm{NS}$ & $\mathrm{NS}$ & $\mathrm{NS}$ & $\mathrm{NS}$ \\
O-Alkyl & $\mathrm{NS}$ & $\mathrm{NS}$ & $\mathrm{NS}$ & $\mathrm{NS}$ & $\mathrm{NS}$ & $\mathrm{NS}$ \\
Methoxyl-C & + & +++ & +++ & +++ & $\mathrm{NS}$ & +++ \\
Aromaticity ratio & $\mathrm{NS}$ & + & $\mathrm{NS}$ & $\mathrm{NS}$ & $\mathrm{NS}$ & $\mathrm{NS}$ \\
Crystallinity & $\mathrm{NS}$ & $\mathrm{NS}$ & $?$ & $\mathrm{NS}$ & $\mathrm{NS}$ & $\mathrm{NS}$ \\
Alkyl-C/COOH & + & + & $\mathrm{NS}$ & + & + & + \\
\hline
\end{tabular}

(NS $=$ Non significant, $+\mathrm{p}<0.05,++\mathrm{p}<0.01,+++\mathrm{p}<0.001)$

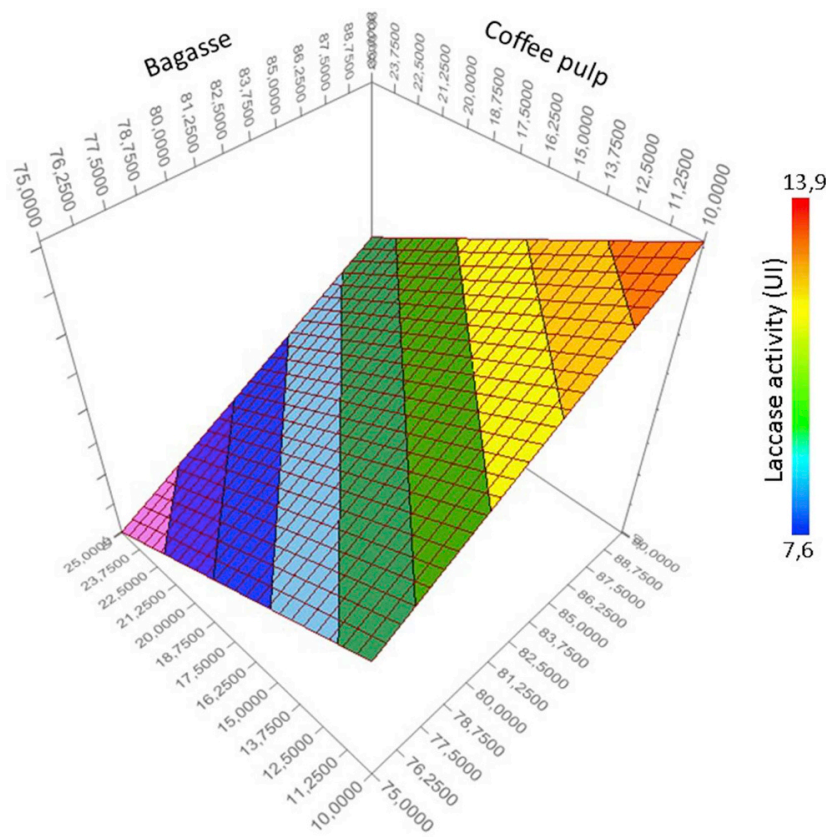

Fig. 3. Laccase activity surface plot of showing the interaction between bagasse and coffee pulp for the second experimental design (Coffee pulp 10-25\%, Urea 0-5\%).

opposite result was found for Alkyl-C/COOH marker: the surface plot interaction between coffee pulp and urea (Fig. 5) showed higher Alkyl$\mathrm{C} / \mathrm{COOH}$ at higher concentrations of coffee pulp and lower concentrations of urea.

The humification rate (Alkyl-C/O-Alkyl-C) was influenced by coffee pulp in interaction with SCB. The surface plot interaction between SCB and coffee pulp showed that for higher concentrations of coffee pulp, this rate increased, which had to be linked with Alkyl-C variations which strongly increased with coffee pulp. Interestingly, the cellulose crystallinity ratio was not affected by any factors under these conditions.

\section{Discussion}

The addition of coffee pulp (10\%) in SCB substrate increased laccase activities, (from 1.6 to $2.1 \mu \mathrm{mol} / \mathrm{g}$ dry weight/h), enhancing delignification. This is supported by SDS-PAGE, which showed that the production of the two constitutive isoforms was enhanced. There are numerous reports about the enhancement of laccase production during SSF using different phenolic compounds which are commonly found in coffee pulp such as ferulic, caffeic, coumaric and chlorogenic acids

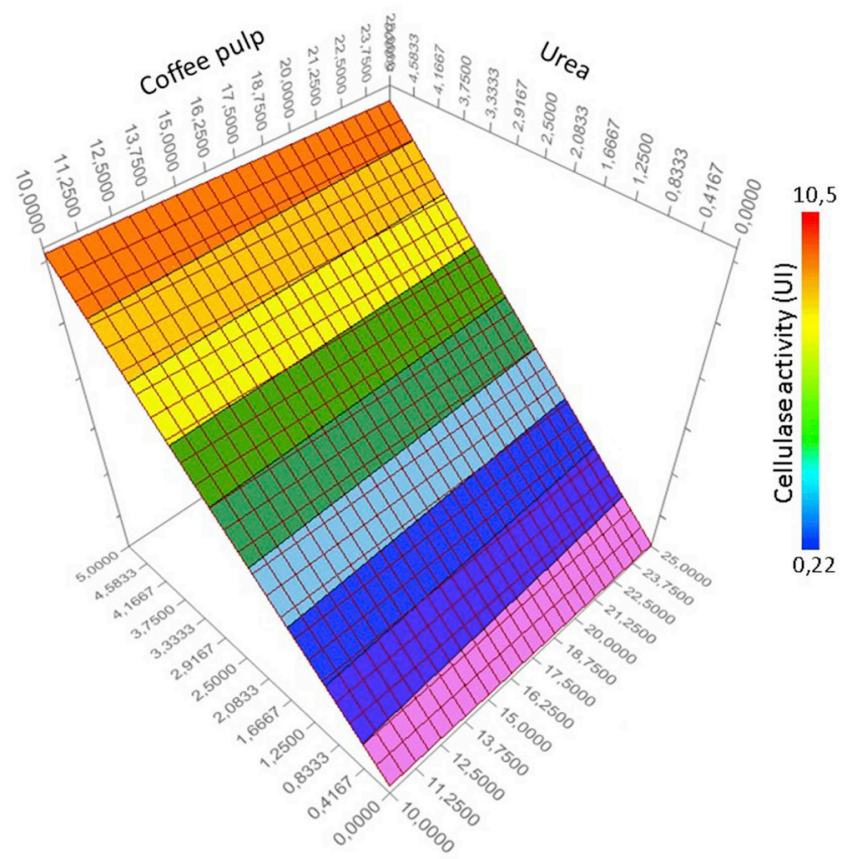

Fig. 4. Cellulase activities surface plot of showing interactions between coffee pulp and urea for the second experimental design (Coffee pulp 10-25\%, Urea 0-5\%).

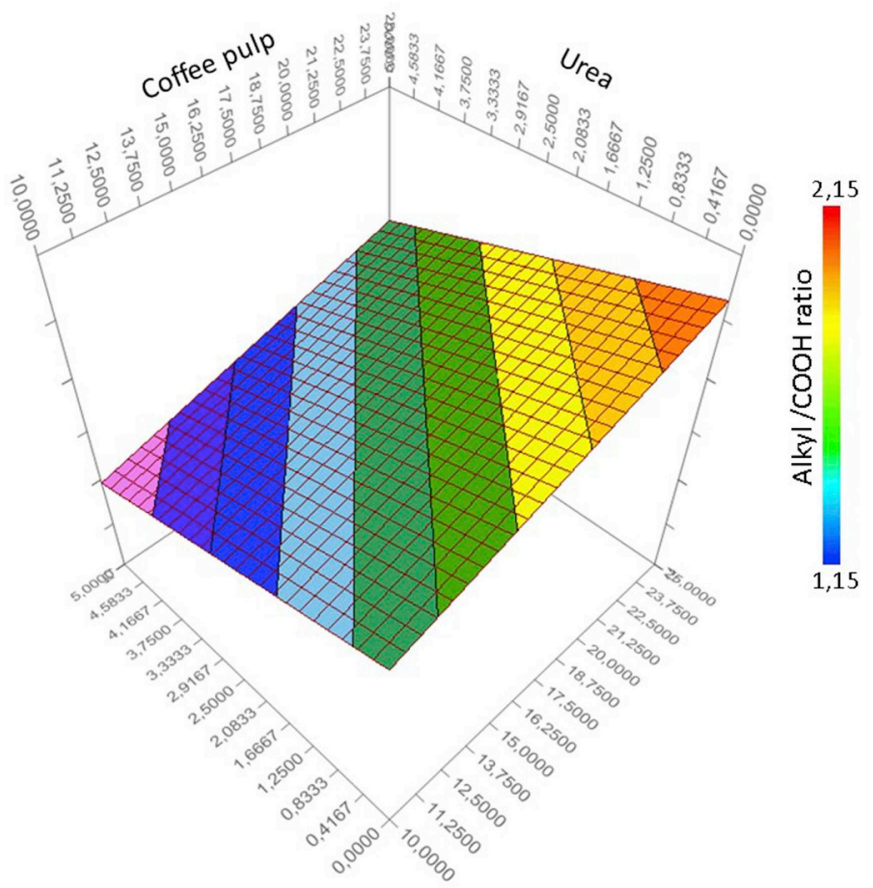

Fig. 5. Alkyl-C/COOH ratio surface plot of showing interactions between coffee pulp and urea for the second experimental design (Coffee pulp 10-25\%, Urea $0-5 \%)$.

(Torres-Mancera et al., 2011). Wang et al. (2017) showed an increase in laccase activities of $150 \%$ when adding a solution of gallic acid in a culture of Pleurotus ostreatus during SSF as well as Yang et al. (2013), who also found higher laccase activities in Trametes velutina using such phenolic compound as an inducer. Zhuo et al. (2017) found that the transcription levels of most laccase genes increased in the presence of ferulic acid, coumaric acid, and cinnamic acid in a culture of Pleurotus 
ostreatus. Laccase production was also qualitatively modified since SDSPAGE revealed that, when adding 10 and $25 \%$ of coffee pulp, a new laccase isoform was produced. These enzymes are known to be induced by various aromatic compounds (Qasemian et al., 2011), as a response developed by microorganisms when substrates are present in their surrounding environment. Collins et al. (1996) observed induction of different isoforms of phenoloxidases by lignin-related phenols. Farnet et al. $(1999,2011)$ found that different phenolic compounds like ferulic acid, gallic acid, vanillic acid or $p$-OH benzoic acid increased the number of isoforms produced by the white-rot fungus Marasmius quercophilus compared with control. Laccases from this white-rot fungus were also found to be induced by different aromatic pollutants like anthracene, and this resulted in a better degradation of the toxic compound (Qasemian et al., 2011).

However, higher concentrations of coffee pulp (25\%) led to a decrease in both laccase and cellulase activities. In our study, laccase activities were measured after a one-month incubation time. Addition of a high amount of coffee pulp (25\% of the substrate) may have accelerated the dynamic of laccase production during the early period of culture. For instance, Téllez-Téllez et al. (2008) found that laccase production of Pleurotus ostreatus, reached a peak of production between 8 and 14 days during SSF. However, in our study, no decrease in aromaticity was observed after adding coffee pulp at $25 \%$ of the substrate, conversely to what we found with $10 \%$ of coffee pulp. Previous studies reported that fungal culture substrate could be complemented with coffee pulp using percentages ranging from $50 \%$ to $95 \%$ with no toxic effect for the development of the fungi (Salmones et al., 2005; González et al., 2013). This can be explained by the fact that phenols are polymerised within the coffee pulp and are gradually degraded by laccases and other ligninolytic enzymes, limiting their toxicity. In this study, sterilization of coffee pulp in water probably led to the extraction of monophenolic compounds with low-molecular-weight. These compounds can cause loss of biological membrane integrity, affecting their role of selective barriers. Moreover, they can inhibit enzyme activities directly via binding on the active site or indirectly via protein precipitation (Klinke et al., 2004; Piscitelli et al., 2011). Phenolic compounds like tannins can react with sulfhydryl groups of the enzymes and form a covalent bond, leading to a strong decrease in enzyme activities (Scalbert, 1991). Concerning enzyme inhibition by phenols, several studies have reported the negative effect of these compounds on bacterial (González-Bautista et al., 2017) and fungal cellulases (Kumar et al., 2008).

The addition of $25 \%$ of coffee pulp in the substrate led to an increase in the amount of biomass produced as revealed by Alkyl-C/COOH ratio, linked to the aliphatic part of phospholipids from the fungal cell membrane (Farnet et al., 2013; Lundberg et al., 2001). The addition of this by-product rich in nitrogen (approximately $10.5 \%$ of dry weight, Pandey et al., 2000) could enhance the production of fungal biomass. Delfín-Alcalá and Durán-de-Bazúa (2003) used a mixture (1:1) of coffee pulp with different urban wastes (cellulosic part of soiled diapers and garden grass residues) in order to improve lignocellulose degradation by Pleurotus ostreatus. Pandey et al. (2000) reported that the use of coffee pulp/husk combined with other vegetal debris, has been shown to be an excellent substrate for production of fungal biomass especially fruiting bodies of Pleurotus ostreatus and Volvariella volvacea in SSF.

Regarding nitrogen sources, this study revealed that urea, even at low concentrations, inhibited laccase production (a range of $\mathrm{C} / \mathrm{N}$ ratio from 10 to 50 was tested here) and hampered delignification, while coffee pulp, via laccase induction, enhanced phenol removal. Laccase expression is regulated by several different biotic and abiotic factors (xenobiotics, metal ions, heat-shock response or microbial antagonisms) and one of the most important is $\mathrm{C} / \mathrm{N}$ ratio (Janusz et al., 2013). White-rot fungi are more capable of degrading lignocellulosic biomass with C/N ratio around 30:1 (D'Agostini et al., 2015), but the effect of C/ $\mathrm{N}$ ratio on production of ligninolytic enzymes can vary with the fungal species. For Pleurotus ostreatus, Lentinus edodes and Agaricus blazei, laccase production was stimulated by low carbon to nitrogen ratio (C) $\mathrm{N}=5$ ), (D'Agostini et al., 2015). On the other hand, Tychanowicz (2004) reported an increase in $60 \%$ of laccase activities from Pleurotus pulmonarius cultured on corncob with a $\mathrm{C} / \mathrm{N}$ ratio around 30:1. The nature of the nitrogen source can also affect the expression of laccases in white-rot fungi. Simple organic sources of nitrogen like urea, are consumed by white-rot fungi like Pycnoporus cinnabarinus, or Phlebia radiata, with the objective of saving cell resources and energy and this usually leads to a low level of laccase activities (Mikiashvili et al., 2006). On the other hand, complex organic nitrogen sources such as mixtures of amino acids, peptones or yeast extract can increase the expression of different enzymes like proteases, L-asparaginase or laccase in order to degrade the different compounds of complex nitrogen sources (Kalisz et al., 1986). Yeast extract can also be considered as an enrichment of the medium, including growth factors, which favour the whole metabolism of the fungus. Low concentrations of nitrogen can unleash the expression of proteases and laccases that are required to improve nitrogen assimilation. This is corroborated by our results since laccase activities of $P$. sanguineus were higher in mesocosms 'control' i.e. without urea and just complemented with yeast extract.

In our study, the addition of urea limited laccase activities but favoured cellulases though neither the crystallinity ratio nor O-Alkyl-C signal varied. Hernández et al., in 2017, reported that, when $P$. sanguineus selectively delignified SCB, by $32.67 \%$ in 16 days, less than $2 \%$ of polysaccharides were degraded. This means that the polysaccharide fraction remained almost unchanged during SSF. This is of importance since preserving polysaccharides for the further steps of bioethanol production (i.e. saccharification and fermentation) meets the objectives of this study. The weak transformation of labile C-source can be linked to the fact that urea addition did not favour biomass production. Consequently, although urea can be considered as a cheap source of nitrogen for fungal growth in SSF (Reddy et al., 2003) and submerged liquid culture (Hernández et al. 2015; Zimbardi et al., 2016; Marim et al., 2016), in our study, it was not favourable for both induction of laccase activities and fungal growth.

Most studies reported the combined use of chemical attacks (delignification) and enzymes (xylanases, cellulases...) for lignocellulosic pre-treatment prior to fermentation. Here, a biological delignification was realised by inducing the phenoloxidase enzymatic system of a white-rot fungus cultivated on SCB. Moreover, many previous studies on laccase induction of white-rot fungi showed that various expensive components (monophenols, yeast extract) were used (Table 5). Here we found that coffee pulp, a cheap agricultural by-product rich in phenolic compounds, containing also minerals and nitrogen sources, could efficiently induce laccase activity up to a threshold. Eventually, the culture conditions defined here led to the selective oxidation of lignin by the white-rot fungus without extensive consumption of polysaccharides (Blanchette, 1995).

\section{Conclusions}

This study revealed that the complementation of SCB with a recalcitrant by-product like coffee pulp, can increase laccase activities and also induce new isoforms of laccases, leading to a decrease in the total aromatics of SCB. However, these promising results were obtained up to a threshold of coffee pulp (10\%), which seems to be toxic for the fungus at higher concentrations. Very interestingly, fungal biomass increased with coffee pulp addition but no strong hydrolysis of polysaccharides was observed, saving these polymers for the next step of second-generation ethanol production. On the other hand, we observed that simple organic sources of nitrogen like urea, limited laccase activities and also affected fungal development of $P$. sanguineus during SSF. Thus here, coffee pulp complementation of the substrate seems to be a promising strategy for pre-treatment of lignocellulose, and other nitrogen sources should be further tested to limit laccase inhibition. 
Table 5

Lignocellulosic materials used as a substrate for laccase production and different enrichment techniques used to enhance laccase activity during SSF.

\begin{tabular}{|c|c|c|c|c|}
\hline Lignocellulosic material & White-rot fungal strain & Culture complementation to induce laccase & Laccase activity & Reference \\
\hline Apple pomace & Phanerochaete chrysosporium & Veratryl alcohol ( $3 \mathrm{mmol} / \mathrm{kg})$ & $789 \mathrm{U} / \mathrm{gdw}$ & Gassara et al. (2011) \\
\hline Beech tree leaves & Pleurotus dryinus IBB 903 & Peptone $(40 \mathrm{mM})$ & $15.6 \mathrm{U} / \mathrm{gdw}$ & Kachlishvili et al. (2006) \\
\hline Barley bran & Trametes versicolor & Xylidine (1 mM) & $1700 \mathrm{U} / \mathrm{L}$ & Couto et al. (2002) \\
\hline Brewery waste & Phanerochaete chrysosporium & Veratryl alcohol $(1.5 \mathrm{mmol} / \mathrm{kg})$ & $841 \mathrm{U} / \mathrm{gdw}$ & Gassara et al. (2011) \\
\hline Coffee husk & Trametes pubescens & $\mathrm{CuSO} 4(5 \mathrm{mM})$ & $110 \mathrm{U} / \mathrm{L}$ & Gonzalez et al. (2013) \\
\hline Coffee pulp & Ganoderma sp & & $142 \mathrm{U} / \mathrm{gdw}$ & Revankar et al. (2007) \\
\hline Flower Stems & Pycnoporus sanguineus SYBC-L1 & Gallic acid $(40 \mu \mathrm{M})$ & $7.26 \mathrm{U} / \mathrm{gdw}$ & Wang et al. (2017) \\
\hline Horticultural waste & Trametes versicolor & Veratryl alcohol (1 mM) & $8.6 \mathrm{U} / \mathrm{gdw}$ & Xin et al. (2011) \\
\hline Peanut shell & Pycnoporus spp SYBC-L3 & & $5 \mathrm{U} / \mathrm{gdw}$ & Liu et al. (2018) \\
\hline Rice husks and straw & Ganoderma lucidum E47 & & $10.9 \mathrm{U} / \mathrm{gdw}$ & Postemsky et al. (2017) \\
\hline Rice straw & Polyporus sanguineus & Malt extract $(0.5 \%)$ & $4.510^{-2} \mathrm{U} / \mathrm{mL}$ & Arora and Gill (2001) \\
\hline Sawdust-based medium & Ganoderma lucidum & Malt extract $(12 \mathrm{~g} / \mathrm{L})$ & $1.1 \mathrm{U} / \mathrm{gdw}$ & Kuhar et al. (2015) \\
\hline \multirow[t]{6}{*}{ Sugarcane bagasse } & Polyporus sanguineus & Malt extract $(0.5 \%)$ & $8.9910^{-2} \mathrm{U} / \mathrm{mL}$ & Arora and Gill (2001) \\
\hline & Pycnoporus sanguineus & Ethanol $(3 \mathrm{~g} / \mathrm{L})$ and yeast extract $(2 \mathrm{~g} / \mathrm{L})$ & $31.01 \mathrm{U} / \mathrm{L}$ & Hernández et al. (2015) \\
\hline & Pycnoporus cinnabarinus ss 3 & Ethanol $\left(10 \mathrm{~g} / \mathrm{m}^{3}\right)$ & $90 \mathrm{U} / \mathrm{gdw}$ & Meza et al. (2005) \\
\hline & Pleurotus ostreatus PO45 & & $35 \mathrm{U} / \mathrm{mL}$ & Dong et al. (2013) \\
\hline & Pleurotus ostreatus & & $112 \mathrm{U} / \mathrm{gdw}$ & Verma et al. (2002) \\
\hline & Pycnoporus sanguineus U13-4 & $\mathrm{CuSO}_{4}(200 \mu \mathrm{M})$ & $35 \mathrm{U} / \mathrm{mL}$ & Marim et al. (2016) \\
\hline Sugarcane molasses & Agaricus blazei & Ethanol $(1.2 \mathrm{mM})$ & $9.7 \mathrm{U} / \mathrm{mL}$ & Valle et al. (2014) \\
\hline \multirow[t]{3}{*}{ Wheat Bran } & Ganoderma sp & $\mathrm{CuSO}_{4}(1 \mathrm{mg} / \mathrm{g})$ & $10,05 \mathrm{U} / \mathrm{gdw}$ & Revankar et al. (2007) \\
\hline & Pleurotus ostreatus IE 137 & & $145 \mathrm{U} / \mathrm{gdw}$ & Mata (2005) \\
\hline & Fomes fomentarius MUCL 35117 & $\mathrm{CuSO}_{4}(5.5 \mathrm{mg} / \mathrm{g})$ & $40 \mathrm{U} / \mathrm{gdw}$ & Neifar et al. (2011) \\
\hline Wheat bran and corncob & Pycnoporus sanguineus RP15 & $\mathrm{CuSO}_{4}(50 \mathrm{mM})$ & $138.6 \mathrm{U} / \mathrm{gdw}$ & Zimbardi et al. (2016) \\
\hline \multirow[t]{3}{*}{ Wheat straw } & Lentinus edodes IBB 363 & $\left(\mathrm{NH}_{4}\right) \mathrm{NO}_{3}(10 \mathrm{mM})$ & $16.5 \mathrm{U} / \mathrm{gdw}$ & Kachlishvili et al. (2006) \\
\hline & Polyporus sanguineus & Malt extract $(0.5 \%)$ & $8.310^{-2} \mathrm{U} / \mathrm{mL}$ & Arora and Gill (2001) \\
\hline & Lentinus edodes IBB 123 & Yeast extract $(4 \mathrm{~g} / \mathrm{l})$ & $228 \mathrm{U} / \mathrm{L}$ & Elisashvili et al. (2008) \\
\hline
\end{tabular}

\section{Conflicts of interest}

All authors declare that they have no conflict of interest in this study.

\section{Acknowledgements}

The authors are grateful to the National Commission for Science and Technology (CONACYT) of Mexico, for the doctoral scholarship of Enrique González Bautista no. 440596and to ECOS-ANUIES-CONACYT Program through the ECOS project M13A02, for financial support. We would like to thank Mrs Lisa FOLI for her helpful technical support during this project.

\section{References}

Alvira, P., Tomás-Pejó, E., Ballesteros, M.J., Negro, M.J., 2010. Pre-treatment technologies for an efficient bioethanol production process based on enzymatic hydrolysis: a review. Bioresour. Technol. 101, 4851-4861.

Arora, D.S., Gill, P.K., 2001. Effects of various media and supplements on laccase production by some white rot fungi. Bioresour. Technol. 77, 89-91.

Arora, D.S., Rampal, P., 2002. Laccase production by some Phlebia species. J. Basic Microbiol. 42, 295-301.

Baldock, J.A., Oades, J.M., Nelson, P.N., Skene, T.M., Golchin, A., Clarke, P., 1997. Assessing the extent of decomposition of natural organic materials using solid-state 13C NMR spectroscopy. Soil Res. 35, 1061-1084.

Baldrian, P., 2006. Fungal laccases-occurrence and properties. FEMS Microbiol. Rev. 30, 215-242.

Bhat, M.K., 2000. Cellulases and related enzymes in biotechnology. Biotechnol. Adv. 18, 355-383.

Blanchette, R.A., 1995. Degradation of the lignocellulose complex in wood. Can. J. Bot. 73, 999-1010.

Box, G.E., Wilson, K.B., 1992. On the Experimental Attainment of Optimum Conditions, Breakthroughs in Statistics. Springer, pp. 270-310.

Chen, S., Ma, D., Ge, W., Buswell, J.A., 2003. Induction of laccase activity in the edible straw mushroom, Volvariella volvacea. FEMS Microbiol. Lett. 218, 143-148.

Collins, P.J., Kotterman, M., Field, J.A., Dobson, A., 1996. Oxidation of anthracene and benzo [a] pyrene by laccases from Trametes versicolor. Appl. Environ. Microbiol. 62, 4563-4567.

Couto, S.R., Gundín, M., Lorenzo, M., Sanromán, M.Á., 2002. Screening of supports and inducers for laccase production by Trametes versicolor in semi-solid-state conditions. Process Biochem. 38, 249-255. https://doi.org/10.1016/S0032-9592(02)00087-0.

D'Agostini, É.C., Mantovani, T.R.D., Valle, J.S. do, Paccola-Meirelles, L.D., Colauto, N.B., Das, A., Mondal, C., Roy, S., 2015. Pre-treatment methods of ligno-cellulosic biomass: a review. J. Eng. Technol. 8.

Dekker, R.F., Barbosa, A.M., Giese, E.C., Godoy, S.D., Covizzi, L.G., 2007. Influence of nutrients on enhancing laccase production by Botryosphaeria rhodina MAMB-05. Int. Microbiol. 10, 177-185.

Delfín-Alcalá, I., Durán-De-Bazúa, C., 2003. Biodegradación de residuos urbanos lignocelulósicos por Pleurotus. Rev. Int. Contam. Ambient. 19, 37-45.

Dong, X.Q., Yang, J.S., Zhu, N., Wang, E.T., Yuan, H.L., 2013. Sugarcane bagasse degradation and characterization of three white-rot fungi. Bioresour. Technol. 131, 443-451.

Elisashvili, V., Penninckx, M., Kachlishvili, E., Tsiklauri, N., Metreveli, E., Kharziani, T., Kvesitadze, G., 2008. Lentinus edodes and Pleurotus species lignocellulolytic enzymes activity in submerged and solid-state fermentation of lignocellulosic wastes of different composition. Bioresour. Technol. 99, 457-462. https://doi.org/10.1016/j. biortech.2007.01.011.

Farnet, A.M., Tagger, S., Le Petit, J., 1999. Effects of copper and aromatic inducers on the laccases of the white-rot fungus Marasmius quercophilus. CR Biol 322, 499-503.

Farnet, A.-M., Criquet, S., Cigna, M., Gil, G., Ferré, E., 2004. Purification of a laccase from Marasmius quercophilus induced with ferulic acid: reactivity towards natural and xenobiotic aromatic compounds. Enzym. Microb. Technol. 34, 549-554.

Farnet, A.M., Qasemian, L., Guiral, D., Ferré, E., 2010. A modified method based on arsenomolybdate complex to quantify cellulase activities: application to litters. Pedobiologia 53, 159-160.

Farnet, A.M., Chevremont, A.C., Gil, G., Gastaldi, S., Ferre, E., 2011. Alkylphenol oxidation with a laccase from a white-rot fungus: effects of culture induction and of ABTS used as a mediator. Chemosphere 82, 284-289.

Farnet, A.-M., Qasemian, L., Peter-Valence, F., Ruaudel, F., Savoie, J.M., Ferré, E., 2013. Capacity for colonization and degradation of horse manure and wheat-straw-based compost by different strains of Agaricus subrufescens during the first two weeks of cultivation. Bioresour. Technol. 131, 266-273.

Gassara, F., Brar, S.K., Tyagi, R.D., John, R.P., Verma, M., Valero, J.R., 2011. Parameter optimization for production of ligninolytic enzymes using agro-industrial wastes by response surface method. Biotechnol. Bioproc. Eng. 16, 343-351. https://doi.org/10. 1007/s12257-010-0264-z.

Gonzalez, J.C., Medina, S.C., Rodriguez, A., Osma, J.F., Alméciga-Díaz, C.J., Sánchez, O.F., 2013. Production of Trametes pubescens laccase under submerged and semi-solid culture conditions on agro-industrial wastes. PLoS One 8, 73721.

González-Bautista, E., Santana-Morales, J.C., Ríos-Fránquez, F.J., Poggi-Varaldo, H.M. Ramos-Valdivia, A.C., Cristiani-Urbina, E., Ponce-Noyola, T., 2017. Phenolic compounds inhibit cellulase and xylanase activities of Cellulomonas flavigena PR-22 during saccharification of sugarcane bagasse. Fuel 196, 32-35.

Gupta, A., Verma, J.P., 2015. Sustainable bio-ethanol production from agro-residues: a 
review. Renew. Sustain. Energy Rev. 41, 550-567.

Hammel, K.E., Kalyanaraman, B., Kirk, T.K., 1986. Oxidation of polycyclic aromatic hydrocarbons and dibenzo [p]-dioxins by Phanerochaete chrysosporium ligninase. J. Biol. Chem. 261, 16948-16952.

Hernández, C.A., Perroni, Y., Pérez, J.A.G., Rivera, B.G., Alarcón, E., 2016. Light-induced inhibition of laccase in Pycnoporus sanguineus. Folia Microbiol. 61, 137-142.

Hernández, C.A., Sandoval, N., Mallerman, J., García-Pérez, J.A., Farnet, A.-M., PerraudGaime, I., Alarcón, E., 2015. Ethanol induction of laccase depends on nitrogen conditions of Pycnoporus sanguineus. Electron. J. Biotechnol. 18, 327-332.

Hernández, C., Da Silva, A.-M.F., Ziarelli, F., Perraud-Gaime, I., Gutiérrez-Rivera, B., García-Pérez, J.A., Alarcón, E., 2017. Laccase induction by synthetic dyes in Pycnoporus sanguineus and their possible use for sugarcane bagasse delignification. Appl. Microbiol. Biotechnol. 101, 1189-1201.

Janusz, G., Kucharzyk, K.H., Pawlik, A., Staszczak, M., Paszczynski, A.J., 2013. Fungal laccase, manganese peroxidase and lignin peroxidase: gene expression and regulation. Enzym. Microb. Technol. 52, 1-12.

Janusz, G., Rogalski, J., Barwinska, M., Szczodrak, J., 2006. Effects of culture conditions on production of extracellular laccase by Rhizoctonia praticola. Pol. J. Microbiol. 55, 309-319.

Kachlishvili, E., Penninckx, M.J., Tsiklauri, N., Elisashvili, V., 2006. Effect of nitrogen source on lignocellulolytic enzyme production by white-rot basidiomycetes under solid-state cultivation. World J. Microbiol. Biotechnol. 22, 391-397.

Kalisz, H.M., Wood, D.A., Moore, D., 1986. Regulation of extracellular laccase production of Agaricus bisporus by nitrogen sources in the medium. FEMS Microbiol. Lett. 34, 65-68.

Klinke, H.B., Thomsen, A.B., Ahring, B.K., 2004. Inhibition of ethanol-producing yeast and bacteria by degradation products produced during pre-treatment of biomass. Appl. Microbiol. Biotechnol. 66, 10-26.

Kuhar, F., Castiglia, V., Levin, L., 2015. Enhancement of laccase production and malachite green decolorization by co-culturing Ganoderma lucidum and Trametes versicolor in solid-state fermentation. Int. Biodeterior. Biodegrad. 104, 238-243.

Koppram, R., Tomás-Pejó, E., Xiros, C., Olsson, L., 2014. Lignocellulosic ethanol production at high-gravity: challenges and perspectives. Trends Biotechnol. 32, 46-53.

Kumar, R., Singh, S., Singh, O.V., 2008. Bioconversion of lignocellulosic biomass: biochemical and molecular perspectives. J. Ind. Microbiol. Biotechnol. 35, 377-391.

Liu, J., Wang, Z., Li, H., Hu, C., Raymer, P., Huang, Q., 2018. Effect of solid-state fermentation of peanut shell on its dye adsorption performance. Bioresour. Technol. 249, 307-314. https://doi.org/10.1016/j.biortech.2017.10.010.

Lundberg, P., Ekblad, A., Nilsson, M., 2001. 13C NMR spectroscopy studies of forest soil microbial activity: glucose uptake and fatty acid biosynthesis. Soil Biol. Biochem. 33, 621-632.

Mansur, M., Suárez, T., González, A.E., 1998. Differential gene expression in the laccase gene family from basidiomycete I-62 (CECT 20197). Appl. Environ. Microbiol. 64 $771-774$

Marim, R.A., Oliveira, A.C.C., Marquezoni, R.S., Servantes, J.P.R., Cardoso, B.K., Linde, G.A., Colauto, N.B., Valle, J.S., 2016. Use of sugarcane molasses by Pycnoporus sanguineus for the production of laccase for dye decolorization. Genet. Mol. Res. 15.

Massiot, D., Fayon, F., Capron, M., King, I., Le Calvé, S., Alonso, B., Durand, J.-O., Bujoli, B., Gan, Z., Hoatson, G., 2002. Modelling one-and two-dimensional solid-state NMR spectra. Magn. Reson. Chem. 40, 70-76.

Mata, G., Hernández, D.M., Andreu, L.I., 2005. Changes in lignocellulolytic enzyme activities in six Pleurotus spp. strains cultivated on coffee pulp in a confrontation with Trichoderma spp. World J. Microbiol. Biotechnol. 21, 143-150.

Mathers, N.J., Xu, Z., 2003. Solid-state 13C NMR spectroscopy: characterization of soil organic matter under two contrasting residue management regimes in a 2-year-old pine plantation of subtropical Australia. Geoderma 114, 19-31.

Meza, J.C., Lomascolo, A., Casalot, L., Sigoillot, J.-C., Auria, R., 2005. Laccase production by Pycnoporus cinnabarinus grown on sugarcane bagasse: influence of ethanol vapours as an inducer. Process Biochem. 40, 3365-3371.

Mikiashvili, N., Wasser, S.P., Nevo, E., Elisashvili, V., 2006. Effects of carbon and nitrogen sources on Pleurotus ostreatus ligninolytic enzyme activity. World J. Microbiol. Biotechnol. 22, 999-1002.

Minussi, R.C., Pastore, G.M., Durán, N., 2007. Laccase induction in fungi and laccase/ $\mathrm{N}-\mathrm{OH}$ mediator systems applied in paper mill effluent. Bioresour. Technol. 98 $158-164$

Mood, S.H., Golfeshan, A.H., Tabatabaei, M., Jouzani, G.S., Najafi, G.H., Gholami, M. Ardjmand, M., 2013. Lignocellulosic biomass to bioethanol, a comprehensive review with a focus on pre-treatment. Renew. Sustain. Energy Rev. 27, 77-93.

Mosier, N., Wyman, C., Dale, B., Elander, R., Lee, Y.Y., Holtzapple, M., Ladisch, M., 2005. Features of promising technologies for pre-treatment of lignocellulosic biomass. Bioresour. Technol. 96, 673-686.

Neifar, M., Kamoun, A., Jaouani, A., Ellouze-Ghorbel, R., Ellouze-Chaabouni, S., 2011. Application of asymmetrical and hoke designs for optimization of laccase production by the white-rot fungus Fomes fomentarius in solid-state fermentation. Enzym. Res. 2, $1-12$.

Niladevi, K.N., Prema, P., 2008. Effect of inducers and process parameters on laccase production by Streptomyces psammoticus and its application in dye decolourization. Bioresour. Technol. 99, 4583-4589.
Pandey, A., Soccol, C.R., Nigam, P., Brand, D., Mohan, R., Roussos, S., 2000. Biotechnological potential of coffee pulp and coffee husk for bioprocesses. Biochem. Eng. J. 6, 153-162.

Park, S., Baker, J.O., Himmel, M.E., Parilla, P.A., Johnson, D.K., 2010. Cellulose crystallinity index: measurement techniques and their impact on interpreting cellulase performance. Biotechnol. Biofuels 3, 10.

Periasamy, R., Palvannan, T., 2010. Optimization of laccase production by Pleurotus ostreatus IMI 395545 using the Taguchi DOE methodology. J. Basic Microbiol. 50, 548-556.

Piscitelli, A., Giardina, P., Lettera, V., Pezzella, C., Sannia, G., Faraco, V., 2011. Induction and transcriptional regulation of laccases in fungi. Curr. Genom. 12, 104-112.

Postemsky, P.D., Bidegain, M.A., González-Matute, R., Figlas, N.D., Cubitto, M.A., 2017 Pilot-scale bioconversion of rice and sunflower agro-residues into medicinal mushrooms and laccase enzymes through solid-state fermentation with Ganoderma lucidum. Bioresour. Technol. 231, 85-93. https://doi.org/10.1016/j.biortech.2017.01. 064.

Qasemian, L., Guiral, D., Belghazi, M., Ferré, E., Gros, R., Farnet, A.-M., 2011. Identification of various laccases induced by anthracene and contribution to its degradation in a Mediterranean coastal pine litter. Chemosphere 84, 1321-1328.

Reddy, G.V., Babu, P.R., Komaraiah, P., Roy, K., Kothari, I.L., 2003. Utilization of banan waste for the production of lignolytic and cellulolytic enzymes by solid substrate fermentation using two Pleurotus species (P. ostreatus and P. sajorcaju). Process Biochem. 38, 1457-1462.

Revankar, M.S., Desai, K.M., Lele, S.S., 2007. Solid-state fermentation for enhanced production of laccase using indigenously isolated Ganoderma sp. Appl. Biochem. Biotechnol. 143, 16-26. https://doi.org/10.1007/s12010-007-0029-0.

Sack, U., Hofrichter, M., Fritsche, W., 1997. Degradation of polycyclic aromatic hydrocarbons by manganese peroxidase of Nematoloma frowardii. FEMS Microbiol. Lett. $152,227-234$.

Salmones, D., Mata, G., Waliszewski, K.N., 2005. Comparative culturing of Pleurotus spp. on coffee pulp and wheat straw: biomass production and substrate biodegradation. Bioresour. Technol. 96, 537-544.

Scalbert, A., 1991. Antimicrobial properties of tannins. Phytochemistry 30, 3875-3883.

Singh, P., Suman, A., Tiwari, P., Arya, N., Gaur, A., Shrivastava, A.K., 2008. Biological pre-treatment of sugarcane trash for its conversion to fermentable sugars. World J. Microbiol. Biotechnol. 24, 667-673.

Sinsabaugh, R.L., 2010. Phenoloxidase, peroxidase and organic matter dynamics of soil. Soil Biol. Biochem. 42, 391-404.

Téllez-Téllez, M., Fernández, F.J., Montiel-González, A.M., Sánchez, C., Díaz-Godínez, G., 2008. Growth and laccase production by Pleurotus ostreatus in submerged and solidstate fermentation. Appl. Microbiol. Biotechnol. 81, 675.

Torres-Mancera, M.T., Cordova-López, J., Rodríguez-Serrano, G., Roussos, S., RamírezCoronel, M.A., Favela-Torres, E., Saucedo-Castañeda, G., 2011. Enzymatic extraction of hydroxycinnamic acids from the coffee pulp. Food Technol. Biotechnol. 49, 369.

Tychanowicz, G.K., Zilly, A., de Souza, C.G.M., Peralta, R.M., 2004. Decolourisation of industrial dyes by solid-state cultures of Pleurotus pulmonarius. Process Biochem. 39, 855-859.

Valle, J.S., Vandenberghe, L.P.S., Santana, T.T., Almeida, P.H., Pereira, A.M., Linde, G.A., Colauto, N.B., Soccol, C.R., 2014. Optimum conditions for inducing laccase production in Lentinus crinitus. Genet. Mol. Res. 13, 8544-8551. https://doi.org/10.4238/ 2014. October.20.31.

Vasconcelos, A.F.D., Barbosa, A.M., Dekker, R.F., Scarminio, I.S., Rezende, M.I., 2000 Optimization of laccase production by Botryosphaeria sp. in the presence of veratryl alcohol by the response-surface method. Process Biochem. 35, 1131-1138.

Verma, P., Madamwar, D., 2002. Production of ligninolytic enzymes for dye decolorization by cocultivation of white-rot fungi Pleurotus ostreatus and Phanerochaete chrysosporium under solid-state fermentation. Appl. Biochem. Biotechnol. 102, 109-118.

Vikineswary, S., Abdullah, N., Renuvathani, M., Sekaran, M., Pandey, A., Jones, E.B.G., 2006. Productivity of laccase in solid substrate fermentation of selected agro-residues by Pycnoporus sanguineus. Bioresour. Technol. 97, 171-177.

Wang, Z., Liu, J., Ning, Y., Liao, X., Jia, Y., 2017. Eichhornia crassipes: agro-waster for novel thermostable laccase production by Pycnoporus sanguineus SYBC-L1. J. Biosci. Bioeng. 123, 163-169.

Xin, F., Geng, A., 2011. Utilization of horticultural waste for laccase production by Trametes versicolor under solid-state fermentation. Appl. Biochem. Biotechnol. 163, $235-246$.

Yang, Y., Wei, F., Zhuo, R., Fan, F., Liu, H., Zhang, C., Ma, L., Jiang, M., Zhang, X., 2013. Enhancing the laccase production and laccase gene expression in the white-rot fungus Trametes velutina 5930 with great potential for biotechnological applications by different metal ions and aromatic compounds. PLoS One 8, e79307.

Zhuo, R., Yuan, P., Yang, Y., Zhang, S., Ma, F., Zhang, X., 2017. Induction of laccase by metal ions and aromatic compounds in Pleurotus ostreatus HAUCC 162 and decolorization of different synthetic dyes by the extracellular laccase. Biochem. Eng. J. 117, $62-72$

Zimbardi, A.L., Camargo, P.F., Carli, S., Aquino Neto, S., Meleiro, L.P., Rosa, J.C., De Andrade, A.R., Jorge, J.A., Furriel, R.P., 2016. A high redox potential laccase from Pycnoporus sanguineus RP15: potential application for dye decolorization. Int. J. Mol. Sci. 17, 672 